\title{
Liverpool Land Basement High, Greenland: visualising inputs for fractured crystalline basement reservoir models
}

\author{
Graham Banks ${ }^{* 1}$, Stefan Bernstein', Sara Salehi', Pierpaolo Guarnieri', Dennis Bird ${ }^{2}$, \\ Catherine Hamblett ${ }^{3}$, David Peacock ${ }^{4}$ and Jon Foster ${ }^{5}$
}

REVIEW ARTICLE | OPEN ACCESS

GEUS Bulletin Vol 43 | e2019430204 | Published online: 22 July 2019

https://doi.org/10.34194/GEUSB-201943-02-04

Basement highs are large structural features, commonly buried in sedimentary basins (Busby \& Azor 2012). They are of interest for natural resources exploration and research because of their ability to influence migration and entrapment of petroleum (Trice 2014) and water, and the deposition of metals (Hitzman 2005; Borg et al. 2012). Three-dimensional (3D) reservoir models (e.g. Shepherd 2009) are built to evaluate and model fluid-filled basement reservoirs (Ringrose \& Bentley 2015). However, subsurface data are expensive, difficult to obtain and are often widely spaced. Ideally, basement reservoir models would be constrained by rock, fracture and mineral vein data from appropriate outcrop analogues (ac- knowledging that subaerial basement rocks have, by definition, a different uplift history than subsurface basement). The Liverpool Land Basement High (LLBH) in Greenland is an uplifted and well-exposed basement high located between two sedimentary basins, and thus provides a valuable analogue for fractured basement-hosted mineral, oil and geothermal reservoirs.

The Geological Survey of Denmark and Greenland (GEUS) conducted reconnaissance work on the LLBH in 2018 to assess the quality of the exposure of basement palaeo-weathering profiles and fault-fracture networks. Here, we introduce the LLBH, the concept of fractured basement

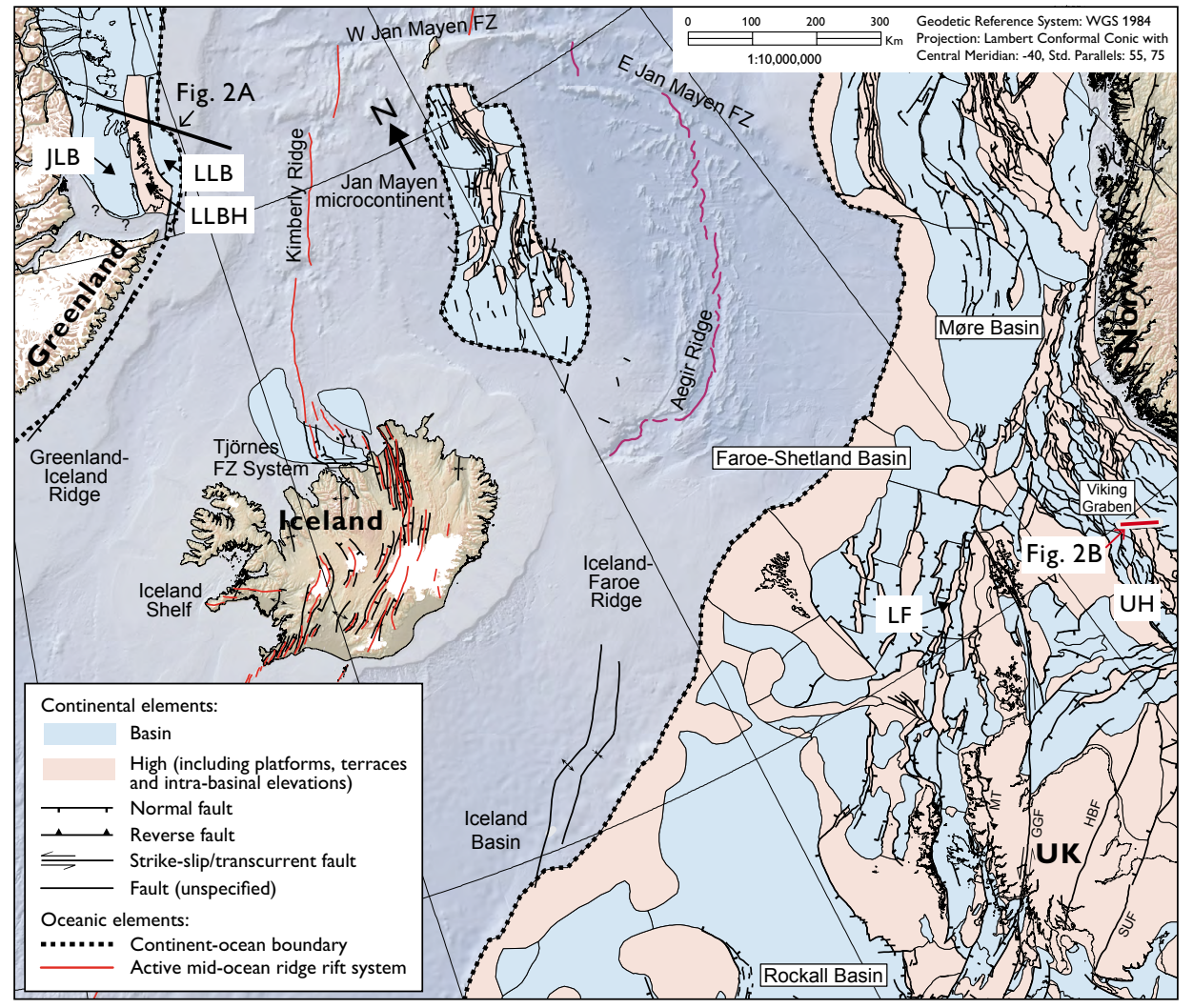

Fig. 1. Locations of North Atlantic Ocean sedimentary basins (blue) and highs (pink). Liverpool Land Basement High (LLBH), Liverpool Land Basin (LLB) and Jameson Land Basin (JLB) are located on the western North Atlantic conjugate margin. The Lancaster field (LF) and Utsira High (UH) basement petroleum reservoirs are located on the eastern North Atlantic conjugate margin (modified from Hopper et al. 2014). 
reservoir modelling, and how studying the LLBH can help enhance reservoir modelling of fractured basement. We present some of our preliminary observations of LLBH faultfracture networks and discuss how the exposed sedimentbasement features and processes might aid industry and research in their top basement mapping activities. We propose that LLBH provides a particularly suitable analogue for industry and research to analyse: (a) multiscale fracture system connectivity, (b) fluid migration and fluid-rock reaction processes, (c) input parameters for basement reservoir modelling and (d) top basement geomorphologies and processes.

'Basement' is here defined as any crystalline lithology and associated regolith. For definitions of fracture, fracture corridor, fault, fault zone, joint, vein and aperture see Peacock et al. (2016).

\section{Liverpool Land Basement High}

LLBH is a Precambrian-Caledonian (Corfu \& Hartz 2011) crystalline basement massif onshore central East Greenland $\left(71^{\circ} \mathrm{N}, 22^{\circ} \mathrm{W}\right)$, located on the western North Atlantic margin, between the offshore Liverpool Land Basin (LLB) and the onshore Jameson Land Basin (JLB; Figs 1, 2). It is mostly comprised of granites, monzodiorites, gneisses and schists, and is the result of multiple tectonic, metamorphic, magmatic, burial, sedimentation, uplift and erosion events (Corfu \& Hartz 2011; Guarnieri et al. 2017). Glacial erosion has generated a deeply incised outcrop $125 \times 35 \mathrm{~km}$, rising up to 1.2 $\mathrm{km}$ a.s.l. LLBH has almost no vegetation cover, so rock exposures continuously display 3D relationships between lithology, structure, weathering and basin sedimentation across a range of scales, from tens of kilometres, down to millimetres (Fig. 3).

LLBH and neighbouring JLB have been explored for decades. Sedimentary copper showings discovered in Permian-Triassic strata by Nordisk Mineselskab and Avannaa Resources-Anglo American were drilled by the latter consortium in 2014 (Guarnieri et al. 2017). JLB hydrocarbon seeps attracted petroleum exploration by ARCO (Atlantic Richfield Company; Guarnieri et al. 2017) and most recently by Greenland Gas \& Oil (Greenland Gas \& Oil 2019). Much tectonic, lithology and petrology research has been conducted upon and offshore LLBH. However, to our knowledge, this review is the first to highlight the potential of the LLBH exposure to visualise input parameters for
Fig. 2. A: Schematic geoseismic section (depth) across Jameson Land Basin (JLB), Liverpool Land Basement High (LLBH) and Liverpool Land Basin (LLB) on the western North Atlantic margin (modified after Hamann, 2005).

Fig. 2. B: Interpreted seismic section (in two-way time) across the Southern Utsira High basement oil fields, eastern North Atlantic margin. The position of the Rolvsnes petroleum discovery in fractured basement is indicated in B. See Fig. 1 for section locations. (Reproduced with permission from Lie $e t$ al. 2016).
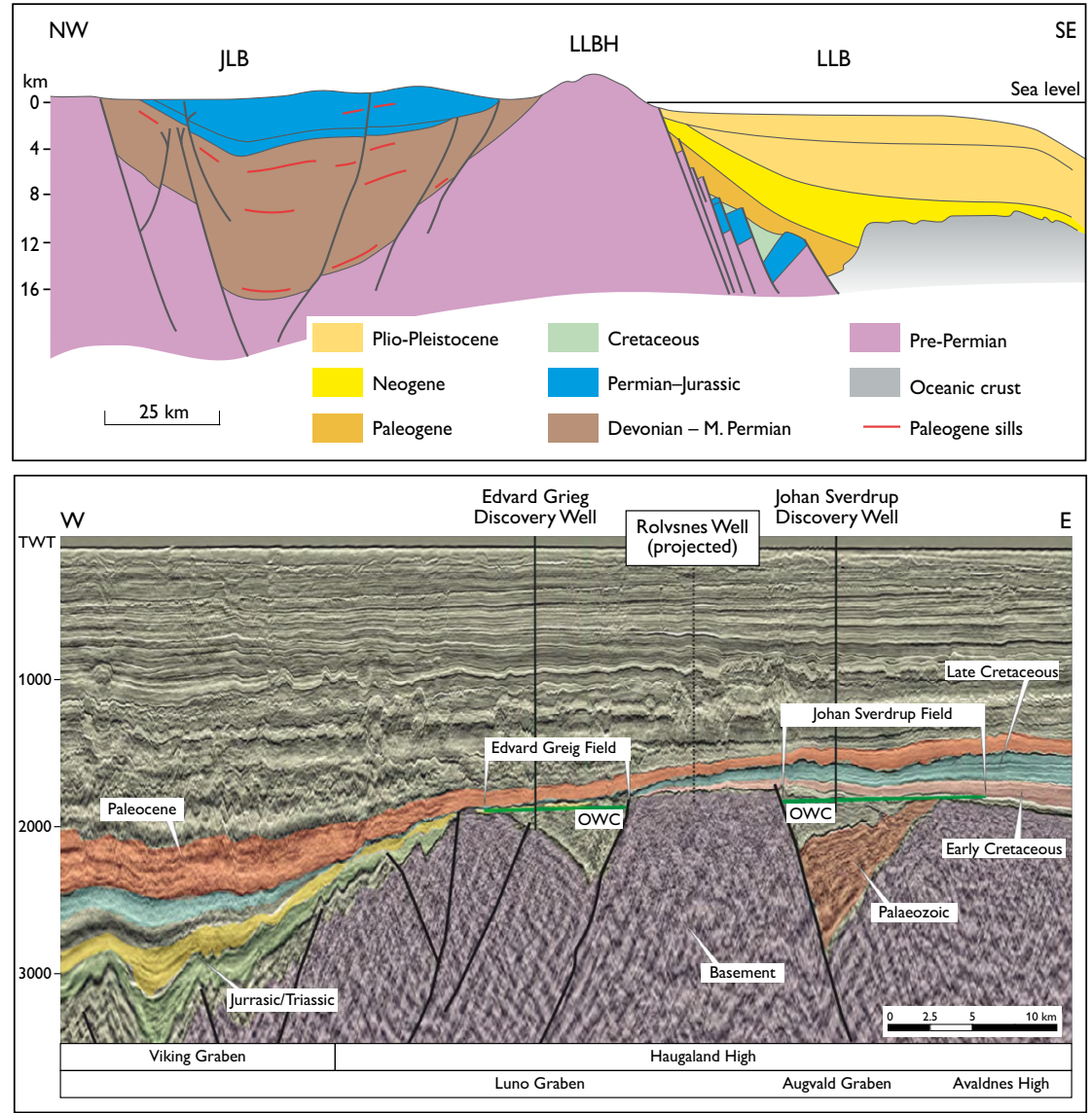
Fig. 3. Spatial scales of input data for fractured reservoir models. Geological outcrops are often limited to the scales indicated by the red dashed line. LLBH encompasses the full range of scales required to cover all fractured reservoir parameters (purple dashed line).

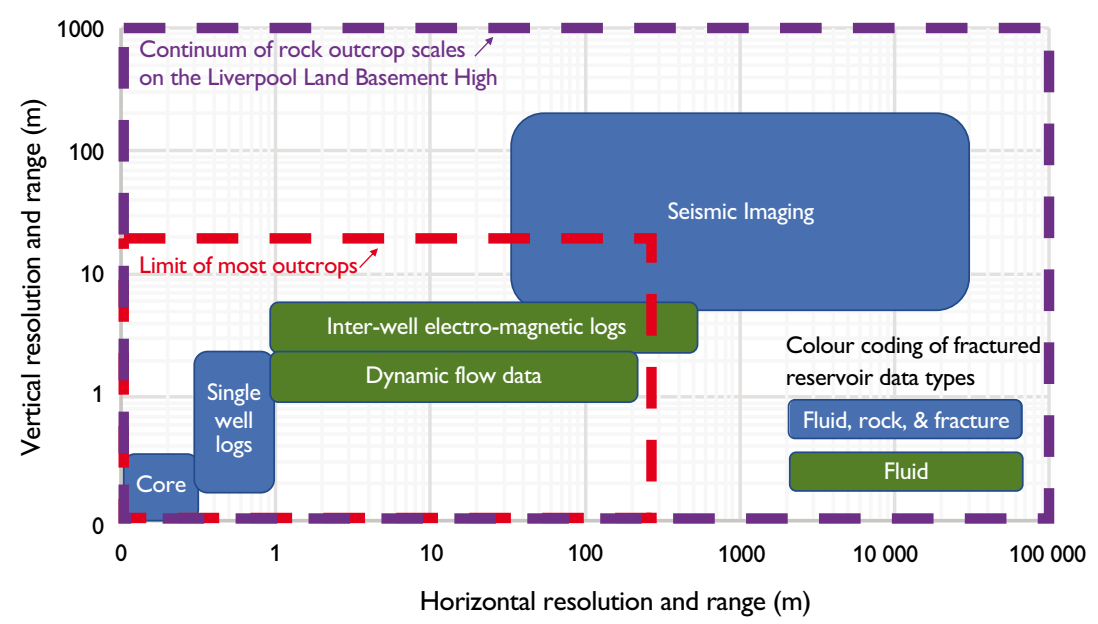

parameters (Shepherd 2009; Ringrose \& Bentley 2015). Applications include estimating trapped fluid volumes, simulating fluid flow and planning where to drill wells. When building a 3D model of a fractured basement reservoir, large-scale basement faults can be interpreted on 3D seismic data (Fig. 4), but most lithology and fault-fracture network properties, e.g. spacing, apertures, porosity, permeability and fluid saturation are below seismic resolution. Characterising sub-metre-scale lithologies and fractures is conducted at the wellbore (e.g. with borehole images, core plug and sonic data), but upscaling and interpolating a fracture system's properties away from the wellbore would be model-driven and highly uncertain. Moreover, some reservoir modellers may not have actually studied extensive 3D fracture systems in the field. The LLBH is a particularly suitable location for fractured basement reservoir geoscientists, modellers and engineers to understand, constrain, extrapolate and interpolate fractured basement properties.

\section{LLBH reconnaissance: initial observa- tions}

Remote sensing and field observations made in 2018 documented the suitability of the LLBH for characterising fracture networks and weathering features needed for a fractured basement reservoir model.

First, a reconnaissance analysis was conducted using Landsat-8 OLI, Sentinel-2 and ASTER spaceborne data, which enabled rapid identification of regional-scale structural lineaments. Fieldwork was then conducted to examine the exposure quality of a range of finer-scale structures (Figs 5A, B, C, D), mostly in an area $c .10 \mathrm{~km}$ east of Nerlerit Inaat (Constable Pynt) Airport and supplemented with aerial observations around LLBH by helicopter. All LLBH 


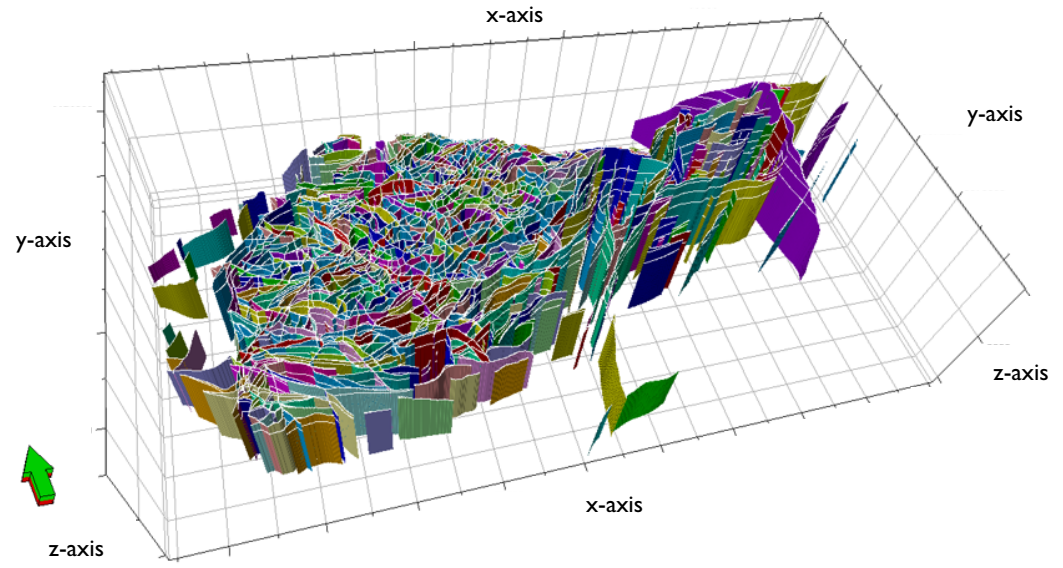

Fig. 4. Fault planes interpreted from seismic data are just one input type for a fractured basement reservoir model. This example is from the Lancaster field (see Fig. 1. for location). The grid cells are $1 \mathrm{~km}^{3}$. The arrow points north, and the green face points to shallower depths. Modelling the intervening reservoir matrix can be facilitated by analysing appropriate analogue outcrops. (Reproduced with permission from Belaidi et al. 2018).

lithologies are pervasively fractured (Figs 5A-D). For example, Hurry Inlet granite outcrops host $100 \mathrm{~m}$ wide corridors of planar joints and chlorite-lined strike-slip fault systems, whilst the Janus $\varnothing$ schist (Fig. 5B) has fractures that reach more than $200 \mathrm{~m}$ in height. Vertical variations in the spacing of fractures in the schist reveal their mechanical stratigraphy.

LLBH is segmented by generally east-west-oriented glacial valleys and fjords, with some cliff outcrops more than $500 \mathrm{~m}$ high. These outcrops display fracture networks at a scale suitable for reservoir model cross-sections. Below seismic scale (Figs 5B, C, D), the rock exposures continue to display fracture network-scaling relationships (e.g. fracture length-height ratios and the number of short versus long fractures) that are vital to realistically populate a fractured basement reservoir model. The frequencies and widths of fault zones and fracture corridors can be observed in 3D (Figs $5 \mathrm{~A}, \mathrm{~B})$. The sparse regolith and vegetation enable systematic analysis of structures, chemical alteration and mineralisation progressively across the fault zones. Between the fault zones and fracture corridors, 10 to $100 \mathrm{~m}$ size blocks of basement 'matrix' are pervasively fractured from metre- to millimetrescales regardless of lithology (Figs 5C, D). Some of the ubiquitous LLBH epidote-quartz-carbonate veins are only partly cemented (Fig. 5D). Such rugose and cement-bridged apertures could maintain effective porosity-permeability in crystalline rocks at reservoir conditions. This shows that whilst some subsurface veins may act as fluid barriers, others could actually contribute to a reservoir's fluid storage and drainage. The sub-metre joints and partly cemented veins also indicate that LLBH is an analogue for dual-porosity basement reservoir types (i.e. both discrete and non-discrete fracture sets contribute to fluid flow; e.g. Belaidi et al. 2018). Characterising LLBH veins can help visualise how to incorporate mineralisation and dissolution history into basement reservoir matrix permeability models.
A reservoir's top basement bedrock and regolith zone may be able to store significant volumes of fluid or mineral resources (Holland 2011) and should be studied in detail. Subsurface seismic interpretations often involve mapping top basement, but this is frequently schematic due to limited top basement resolution or limited knowledge of top basement characteristics. The well-exposed and incised top basement of LLBH (marked by the nonconformity between JLB sedimentary rock and underlying basement) enables detailed study of constituent geomorphologies, weathering facies, regolith types and porosity-permeability networks formed during arid peneplanation (Permian) and glacial (Quaternary) processes. Regolith types include talus slopes, proximal conglomerates, freeze-thaw rubble, proximal outwash plains and kaolinitised peneplains. Top basement in the Kangerterajittap Ilinnera (Klitdal) area forms a nonconformity contact between JLB Pingodal Formation basal conglomerate and gneiss. Here, some of the orthogonal joints in the Pingodal Formation appear to be non-stratabound, i.e. continue into underlying gneisses, and could have connected basin and basement fluid systems.

\section{Conclusions}

Our 2018 reconnaissance suggests that LLBH is a particularly suitable location for petroleum, mineral and geothermal resource sectors to visualise connectivity of dual-porosity basement reservoir fracture networks and mineralisation features continuously across a range of scales. Studying the LLBH could help geoscientists, modellers and engineers to formulate procedures to upscale wellbore data and downscale seismic data in their fractured basement reservoir models. LLBH also provides drilling and reservoir engineers with visual insights into fractured basement heterogeneity. The LLBH top basement displays a range of palaeo-weathering 
W

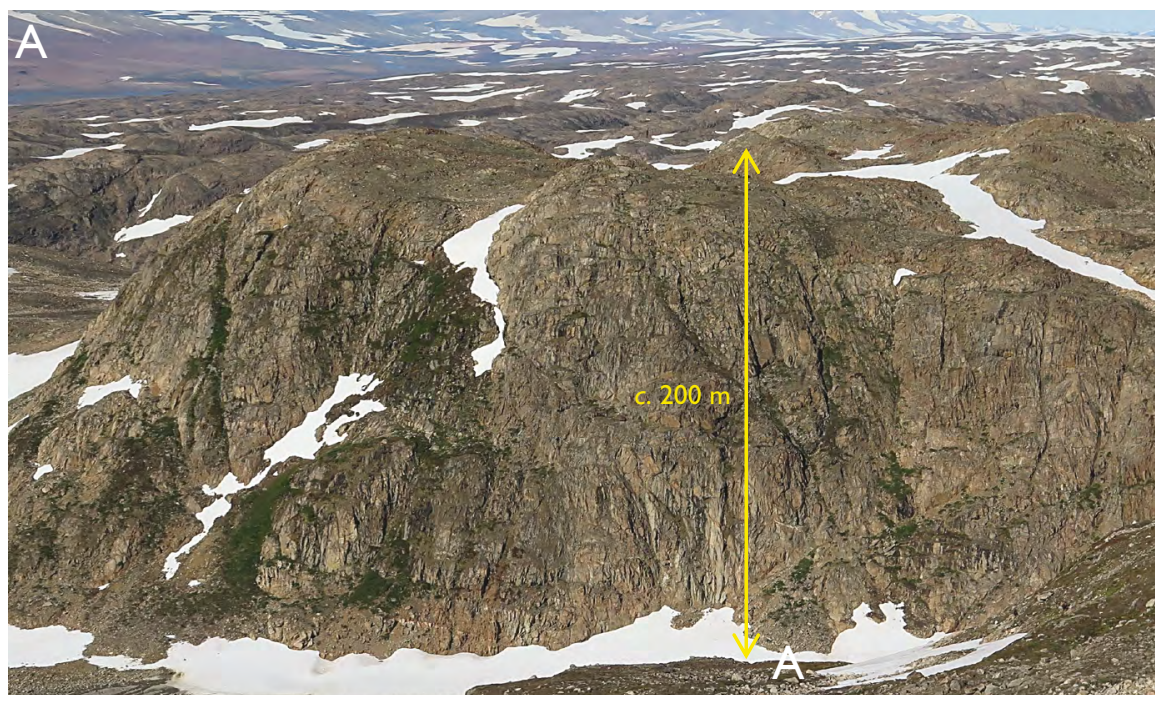

W

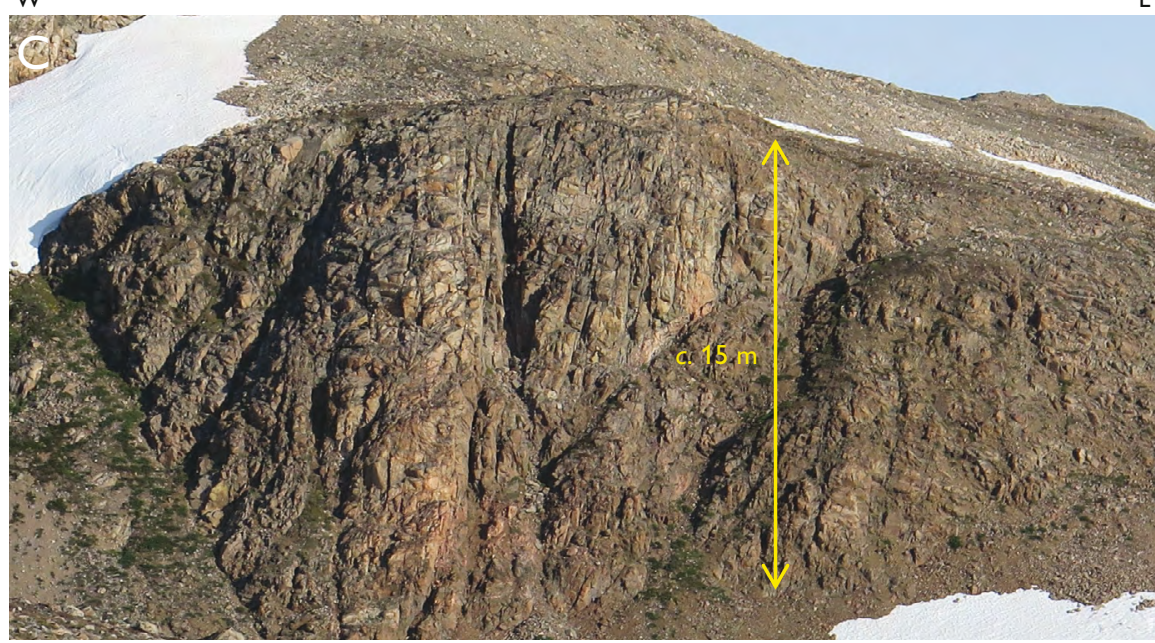

Looking east
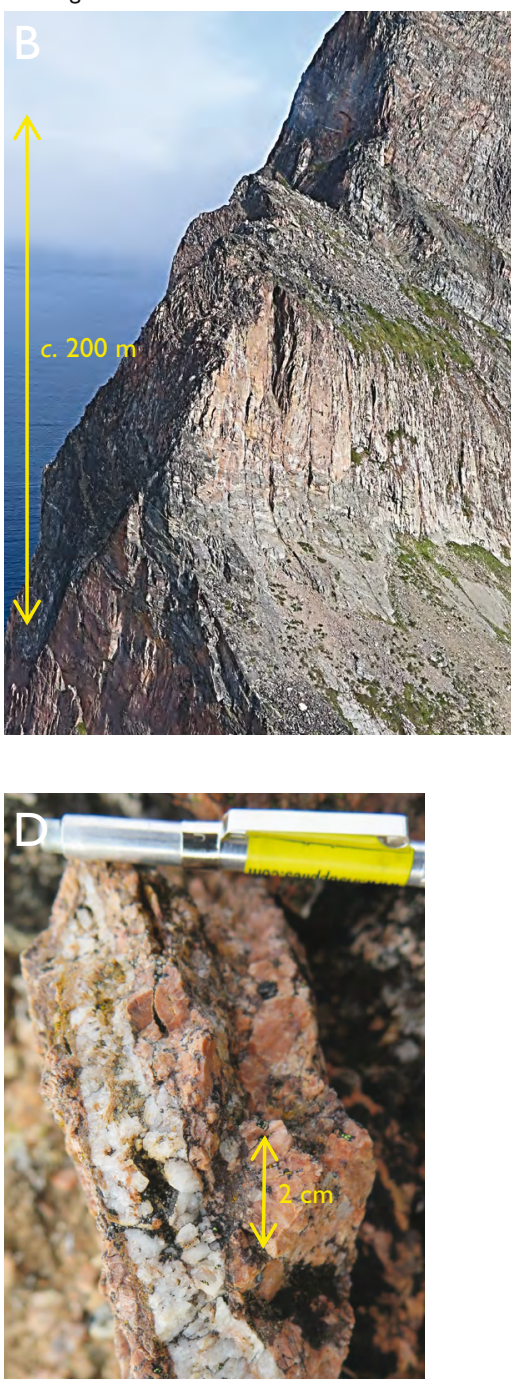

Fig. 5. Reconnaissance of the LLBH. A: Exposure of top basement morphology and 3D fracture network connectivity. B: Pervasive fractures $>200 \mathrm{~m}$ high on Janus $\varnothing$. C: Intense fracturing of basement matrix at the scale of one reservoir model grid cell (sub-kilometre scale). D: Partly-cemented vein aperture at core-plug scale (centimetre-scale).

profiles and glacial geomorphology features to aid any top basement seismic interpretation. The vein mineralisation and dissolution histories exposed on LLBH can help discern the effects of basement highs on basinal brine migration processes during basin- and basement-hosted base metal mineralisation.

The following projects are being considered for further study:

- To collect and interpret photographs of valley/fjord cliffs to 3D-map the laterally continuous fracture networks, and create reservoir-scale virtual outcrops, using photogeological techniques (e.g. Sørensen and Dueholm 2018).

- Organise a workshop on the LLBH in the field to facilitate discussions between reservoir geoscientists, geo- modellers and reservoir engineers of fractured basement reservoir modelling and fracture systems.

- Investigate the Permian-Triassic palaeoenvironments of the JLSB-LLBH nonconformity to understand top basement geomorphologies, evolution and reservoir properties.

\section{Acknowledgements}

We thank the Permian-Triassic of East and North-East Greenland project at GEUS for sponsorship; the GEUS logistics and field equipment team; staff at Nerlerit Inaat (Constable Pynt) Airport and the Air Greenland helicopter crews for their contributions to the 2018 fieldwork. We also thank Tim Needham (Needham Geoscience Limited) and Tom Wesby (First Quantum) for their valuable reviews of this manuscript, Jan Lie 
(Lundin-Norway) for supplying Fig. 2B, Daniel Bonter and Robert Trice (Hurricane Energy) for supplying Fig. 4.

\section{References}

Belaidi, A., Bonter, D.A., Slightam, C. \& Trice R.C. 2018: The Lancaster Field: progress in opening the UK's fractured basement play. In: Bowman, M. \& Levell, B. (eds): Petroleum Geology of NW Europe: 50 Years of Learning - Proceedings of the 8th Petroleum Geology Conference, 385-398.

Borg, G., Piestrzynski, A., Bachmann, G. H., Püttmann, W., Walther, S. \& Fiedler, M. 2012: An overview of the European Kupferschiefer Deposits. In: Hedenquist, J.W., Harris, M. \& Camus, F. (eds): Geology and Genesis of Major Copper Deposits and Districts of the World: A Tribute to Richard H. Sillitoe. Special Publications - Society of Economic Geologists 16, 455-486.

Busby, C. \& Azor, A. (eds). 2012: Tectonics of Sedimentary Basins: Recent Advances, 647 pp. Chichester: Wiley \& Sons.

Corfu, F. \& Hartz, E.H. 2011: U-Pb geochronology in Liverpool Land and Canning Land, East Greenland - the complex record of a polyphase Caledonian orogeny. Canadian Journal of Earth Sciences 48, 473-494. https://doi.org/10.1139/e10-066

Greenland Gas \& Oil A/S, 2019. Available online at: http://www.ggoplc. com/projects/jameson.html

Guarnieri. P., Brethes, A. \& Rasmussen, T. M. 2017: Geometry and kinematics of the Triassic rift basin in Jameson Land (East Greenland). Tectonics 36, 602-614. https://doi.org/10.1002/2016tc004419

Hamann, N.E., Whittaker, R.C. \& Stemmerik, L. 2005. Geological development of the Northeast Greenland Shelf. Geological Society, London, Petroleum Geology Conference Series 6, 887-902. https://doi. org/10.1144/0060887

Hitzman, M., Kirkham, R., Broughton, D., Thorson, J. \& Selley, D. 2005 : The sediment-hosted stratiform copper ore system. In: Hedenquist, J.W. et al. (eds): Economic Geology: One hundredth anniversary volume 1905-2005, 609-642. Littleton, Colorado: Society of Economic Geologists. https://doi.org/10.5382/AV100.19

Holland, M. 2011: Hydrogeological characterisation of crystalline basement aquifers within the Limpopo Province, South Africa, $\mathrm{PhD}$ thesis, University of Pretoria, South Africa.

Hopper, J.R., Funck, T., Stoker, M., Árting, U., Péron-Pinvidic, G., Doornenbal, H. \& Gaina, C. (eds). 2014: Tectonostratigraphic Atlas of the North-East Atlantic Region. Geological Survey of Denmark and Greenland (GEUS), Copenhagen, Denmark.

Lie, J.E., Nilsen, E.H., Grandal, E., Grue, K. \& Sørlie, R. 2016: A successful geophysical prediction of fractured porous basement reservoir - Rolvsnes oil discovery 2015, Utsira High. Extended abstract, 78th EAGE Confer- ence \& Exhibition. Vienna, Austria, 30 May-2 June, 2016. https://doi. org/10.3997/2214-4609.201600593

Peacock, D.C.P., Nixon, C.W., Rotevatn, A., Sanderson, D.J. \& Zuluaga, L.F. 2016: Glossary of fault and other fracture networks. Journal of Structural Geology 92, 12-29. https://doi.org/10.1016/j.jsg.2016.09.008

Ringrose, P. \& Bentley, M. 2015: Reservoir Model Design - A practitioner's guide. 62 pp. Dordrecht: Springer. https://doi.org/10.1007/978-94-0075497-3

Riber, L., Dypvik, H. \& Sorlie, R. 2015: Altered basement rocks on the Utsira High and its surroundings, Norwegian North Sea. Norwegian Journal of Geology 95, 57-89. https://doi.org/10.17850/njg95-1-04

Sheldon, H.A. \& Micklethwaite, S. 2007: Damage and permeability around faults: Implications for mineralization Geology 35, 903-906. https:// doi.org/10.1130/g23860a.1

Shepherd, M. 2009: 3-D geocellular modelling. In: Shepherd, M (ed.): Oil field production geology. American Association of Petroleum Geologists Memoir 91, 175-188.

Sørensen, E.V. \& Dueholm, M. 2018: Analytical procedures for 3D mapping at the Photogeological Laboratory of the Geological Survey of Denmark and Greenland. Geological Survey of Denmark and Greenland Bulletin 41, 99-104.

Trice, R. 2014: Basement exploration, West of Shetlands: progress in opening a new play on the UKCS. Geological Society (London), Special Publications 397, 81-105. https://doi.org/10.1144/sp397.3

Vidal, J., Genter, A. \& Chopin, F. 2017: Permeable fracture zones in the hard rocks of the geothermal reservoir at Rittershoffen, France. Journal of Geophysical Research: Solid Earth 122, 4864- 4887. https://doi. org $/ 10.1002 / 2017 \mathrm{jb} 014331$

Vosgerau, H. et al. 2016: A WebGIS portal for exploration of deep geothermal energy based on geological and geophysical data. Geological Survey of Denmark and Greenland Bulletin 35, 23-26.

Walter, B.F., Gerdes, A., Kleinhanns, I.C., Dunkl, I., von Eynatten, H., Kreissl, S. \& Markl, G. 2018: The connection between hydrothermal fluids, mineralisation, tectonics and magmatism in a continental rift setting: Fluorite $\mathrm{Sm}-\mathrm{Nd}$ and hematite and carbonates $\mathrm{U}-\mathrm{Pb}$ geochronology from the Rhinegraben in SW Germany. Geochimica et Cosmochimica Acta 240,11-42. https://doi.org/10.1016/j.gca.2018.08.012

\section{How to cite}

Banks, G., Bernstein, S., Salehi, S., Guarnieri, P., Bird, D., Hamblett, C., Peacock, D. \& Foster, J. 2019: Liverpool Land Basement High, Greenland: visualising inputs for fractured crystalline basement reservoir models. Geological Survey of Denmark and Greenland Bulletin 43, e2019430204. https://doi.org/10.34194/GEUSB-201943-02-04

\footnotetext{
${ }^{*}$ Corresponding author: Graham Banks |E-mail: gb@geus.dk

${ }^{1}$ Geological Survey of Denmark and Greenland (GEUS), Øster Voldgade 10, DK-1350, Copenhagen K, Denmark.

${ }^{2}$ Department of Geological Sciences, Stanford University, Stanford, California 94305, USA.

${ }^{3}$ Jagersborg Alle 55, 2920 Charlottenlund, Denmark.

${ }^{4}$ Department of Earth Science, University of Bergen, Allégaten 41, 5007 Bergen, Norway.

${ }^{5}$ INEOS Oil \& Gas Denmark, Teknikerbyen 5, 2830 Virum, Denmark.
} 